\title{
Res publica Redefined? The Polish-Lithuanian Transition Period of the 1560s and 1570s in the Context of European State Formation Processes
}

Review Number: 2131

Publish date: Thursday, 6 July, 2017

Author: Miia Ijäs

ISBN: 9783631667125

Date of Publication: 2015

Price: $£ 50.80$

Pages: 304pp.

Publisher: Peter Lang AG

Publisher url: https://www.peterlang.com/view/product/24132?format=HC

Place of Publication: Oxford

Reviewer: Karin Friedrich

Into the relatively small pond of English-language work on the early modern Polish-Lithuanian Commonwealth, the Finnish historian Miia Ijäs has launched a monograph, based on her doctoral dissertation, which will be received with interest. Ijäs, who completed her $\mathrm{PhD}$ at the University of Tampere, tests the waters with an approach that is stimulating, but may in some aspects prove controversial. She argues that constitutional and social changes in 16th-century Polish society was determined by processes of decision-making which need to be reconsidered above all in the context of foreign relations. At first sight, this seems hardly surprising. Obviously, the more we know about the wider context, the better we can judge, according to Rankean historicism - wie es eigentlich gewesen ist - just as it really was. Ijäs's approach though does not hark back to the 19th-century idea of the primacy of foreign policy, nor to its fashionable revival in the works of Brendan Simms and William Mulligan.(1) Rather, she argues that there is a distinct lack of foreign policy perspectives in most treatments of the history of the Polish-Lithuanian state, which she insists must complement the history of religion, political thought and internal institutional developments. These arguments are pursued through a focus on the first two interregna following the extinction in the male line of the ruling Jagiellonian dynasty in Poland in 1572, and the subsequent institution of the right of free election of the monarch by the whole citizen body of nobles.

Ijäs does not immediately begin with the story, which, in seven chapters, will eventually take us from the death of the last Jagiellonian king, Sigismund August (king of Poland 1548-72), to the elections to the Polish throne of Henri of Valois (ruled from February to June 1574) and Stefan Batory (ruled 1575-86). Instead she draws theoretically on the paradigm of transnational history and follows approaches to the study of composite states, particularly influenced by the works of Harald Gustafsson and John Elliott.

In opposition to older approaches which diagnosed a weakening of the Polish monarchy from the end of the Jagiellonian period onwards, the author counts herself among the 'revisionists' who do not believe that the transition from a dynastic to an elective monarchy undermined royal authority. Most importantly, she promises a focus on Poland-Lithuania's relations to its neighbours and the international state system. She is 
frank about the limitations of her study which excludes Lithuanian politics. Despite her admirable range of languages, the author admits that she could not tackle Ruthenian sources. Indeed, to include the whole of Polish-Lithuanian history of the period would have been a tall order. Yet repeatedly, the exclusion of the Lithuanian side of the story - particularly in the shadow of the Union of Lublin of 1569 which joined Poland and Lithuania - leaves a painful gap, especially with regard to the analysis of the composite state's relations with Muscovy and the role of the Lithuanian elites during the political crisis that followed Sigismund August's death.

The introduction outlines the main research question: how did a conglomerate such as the Jagiellonian monarchy survive the highly destabilising period which encompassed two interregna, against the background of profound constitutional and religious change, economic and judicial reform, as well as international pressures, all of which accompanied the royal elections of 1573 and 1575? The selection of a range of candidates for the Polish throne and the conditions set down for them in the so-called pacta conventa, were all driven by debates among the noble estates. 16th-century European history is often associated with the strengthening and centralisation of monarchies. This has usually been characterised as 'state building'. Despite the existence of mixed forms of government elsewhere in Europe, where estates had an influence on government (including France, the Netherlands, the German lands, Switzerland, and Venice), the Polish Ständestaat over time diverged markedly from the modernisation processes typical for most European states. Owing to Poland's resistance to absolute monarchy, it has been singled out as an exception in early modern Europe. Ijäs contradicts this traditional view and insists that even Poland followed a process of 'state formation' which, she believes, consolidated during Stefan Batory's reign from 1575.

The approach is explained in the second chapter. After an excursion via Hegel, Weber, Wallerstein and Tourraine, whose influences are dismissed as unsuitable generalisations based on Western European models and as 'methodological nationalism' (p. 55), Ijäs proposes that the analysis of decision-making processes in multi-ethnic composite states with a mixed constitution, such as early modern Poland-Lithuania, benefits most from Talcott Parsons's social action theory. This approach is based on 'adaption, goal-attainment, integration and latency' (p. 67), pointing at the desire of a given society to preserve its institutions and its own long-term existence. In the late 1990s Joachim Bahlcke and Hans-Jürgen Bömelburg already noted that modernisation in the Ständestaaten in East Central Europe was not necessarily dependent on the growth of state institutions driven by absolute monarchy, but could happen 'from below', initiated by the agency of the estates themselves. In fact, the model of consensus in a participatory system of local and central assemblies, royal elections and decision-making procedures that included the noble citizenry, was just as capable of 'building' institutions such as the crown tribunal, implemented religious toleration and conducted military and tax reform.(2) Unfortunately, this influential work is missing from the bibliography.

Keeping her promise to link theory and practice, Ijäs then presents the reform proposals of two political theorists, who also launched their professional life in politics during the late Jagiellonian period: Stanis?aw Orzechowski, the Catholic priest from the Ruthenian borderlands, who rejected priestly celibacy, married, and yet managed to remain a Catholic priest; and Andrzej Frycz Modzrewski, the political theorist and religious non-conformist. While both are considered important thinkers, Frycz Modrzewski, during his lifetime was more influential outside Poland than in his own country. He alienated some contemporaries who suspected him of Antitrinitarian sympathies. While the juxtaposition of Modrzewski (as a 'pro-tolerance' thinker) versus Orzchowski (as a Catholic defender of 'hierarchy)' seems attractive and imposes a neatly polarised view of Polish political and religious ideologies (Protestant and republican versus Catholic and monarchist), this divide was much less clear-cut in reality. In particular, with regard to the Realpolitik of the Sejm and the constant manoeuvring on issues of religion, taxation and jurisdiction during the two first interregna, this dualistic view only enforces older stereotypes instead of providing a fresh perspective. Toleration was not the same as tolerance, as Ben Kaplan has reminded us repeatedly: early modern 'toleration' meant to 'suffer' those who had a different belief or denomination, not liberal acceptance. There was a sizeable community of Polish Catholic politicians, including bishops, who adopted the role of mediators, similar to the 'politiques' in 16th-century France. It was in this limited sense - thanks to an awareness of the necessity of regulation to avoid bloodshed that had plagued so much of Europe during the 
multiple religious wars elsewhere - that the Confederation of Warsaw of 1573 was signed by so many noblemen with diverging confessional allegiances. Moreover, with this act, liberty of conscience became on of the nobles' golden liberties.

The book is structured according to Parsons's four social actions. In four main chapters, Ijäs distinguishes the Polish nobility's continuous recognition of political obstacles, such as the end of the dynasty in 1572 (latency), the forging of the union of 1569 and the resulting need for the accommodation of religious and ethnic pluralism in the Confederation of Warsaw of 1573 (integration), the elections of 1573 and 1575 (goalattainment) and the successful endurance of the composite state under Stefan Batory after 1575 (adaption and again latency).

While this structure is stimulating, I am not sure that Parsons's scheme is relevant to the narrative of 'state formation' between the 1560s and 1575. Each chapter contains a conclusion that refers back to the link with one of Parsons's social action stages, but also appears somewhat artificial and imposed. Perhaps most importantly, there is a fundamental lack of clarity with regard to what constituted the 'state' and what constituted the 'res publica' - two rather different political concepts which are frequently confused. As Ijäs rightly emphasises, most political theorists stressed the role of the community, formed by the nobility in the local and central assemblies, which passed laws after reaching a consensus. While the res publica required institutions - which formed the state (pa?stwo in Polish) - the res publica (Rzeczpospolita) was increasingly embodied by the citizens active through the institutions of self-government (tribunals, diets, local offices, etc.), based on justice and participation. In other words, while state was form, res publica was content. Parsons's theory does not help clarify the distinction between the functioning of the Rzeczpospolita and the construction of the pa? stwo. At times 'state' is equated with dynasty (p. 116), but it remains unclear how decision-making worked in order to produce a result among the large numbers of nobles involved at various local and regional levels, and how central decisions were made. Did these processes reflect 'state-formation', or actions of the Rzeczpospolita?

The book aims at demonstrating the working of a composite state. Yet there is no clear distinction between the political positions and conflicts among the non-Polish parts of the Commonwealth, especially in the border regions, which had a singularly important influence on foreign policy. How representative were the views of the few selected magnates that dominate the history books? There is scant regard for the Lithuanian lower nobility who embraced the idea of the res publica, aspiring to the theoretical equality with the Polish nobility that the union of 1569 had granted them. While the elements of each state - Poland and Lithuania remained separate after the union of 1569 , the res publica grew together. These ambiguities could have been alleviated by a more thorough reading of existing Polish historiography. Several key works by Polish authors and in Polish on the Grand Duchy of Lithuania are missing from the bibliography, such as Henryk Lulewicz's seminal study on the frequently difficult relationship between Lithuania and Poland.(3)

The most successful part of the book focuses on the impact of foreign affairs on decision-making during the election processes of 1572-3 and 1574-5, and particularly the influence - often ignored in standard narratives of this period - of the Ottoman sultans Selim II and Murad III. As with religious conflicts, the nobility's wish to preserve the peace pragmatically transcended other agendas and won the day, at least in the short term. The reminder that the Jagiellonian legacy is deeply influenced by an outlook on the East and Central East of Europe, is indeed important when we discuss alleged Polish 'exceptionalism'. 
The author has used interesting materials from Swedish archives and the Vatican. This provides fresh perspectives on the elections and their European context. Somewhat problematic, however, is the omission of vital secondary works on the later 16th century, such as Michael Müller's study on the religious tensions in Royal Prussia - another part of the 'conglomerate' of the composite state - and the seminal work by Gottfried Schramm on the effects of the Reformation in Poland, by Anna Sucheni-Grabowska on the execution movement of the 1560s and matters of taxation, and by Anna Filipczak-Kocur on the Lithuania treasury. They all would have thrown an important light on the very institutions which 'state formation' produced.

Very welcome is the thesis that the estates essentially desired a strong monarch during the first two elections. Ijäs follows here Felicia Ro?u's forthcoming book on the election of Stefan Batory and its Transylvanian dimension. In the light of this claim the reader would have wished to gain more detailed insight into the intricacies of the elections. It hardly matters whether Batory's success corresponded to Parsons's stage of latency or adaptation. Instead, it would have been useful to have a clearer indication as to why the Russians were unsuccessful in pushing their candidate, and why Henry of Anjou was successful in 1573, despite being implicated in the massacre of Saint Bartholomew. The argument that he appeared 'strong enough' as a royal candidate does not convince.

Poland-Lithuania certainly consolidated as a 'state' under Stefan Batory's reign. It also increasingly grew together as a commonwealth. There is no doubt that the king's foreign policy contributed to this. Whether the success of Tridentine Catholicism has anything to do with this consolidation, though, remains doubtful. The success of the Polish model of individual noble liberty and the effective integration of the various parts of the Commonwealth relied not so much on the strengthening of Catholic Counter-Reformation but on a supra-confessional consensus that the defence of constitutional liberties against tyranny and the preservation of self-government were worth fighting for. This consensus started to break down, but this happened mainly after Batory's reign.

Despite these problems, this is a thought-provoking book which stimulates new questions. With a stronger and more coherent focus on the details of decision-making during the two elections, and less attention to the questionably relevant theoretical superstructure, this book would have left a stronger impression on scholars of early modern Poland-Lithuania. Historians of Europe will find it useful for its thoughtful references to the wider European context. Finally, it is regrettable that the publisher did not encourage the addition of an index.

\section{Notes}

1. Brendan Simms and William Mulligan, The Primacy of Foreign Policy in British History, 1660-2000. How Strategic Concerns Shaped Modern Britain (Basingstoke, 2010).Back to (1)

2. Ständefreiheit und Staatsgestaltung in Ostmitteleuropa: Übernationale Gemeinsamkeiten in der politischen Kultur vom 16.-18. Jahrhundert, ed. Joachim Bahlcke, Hans-Jürgen Bömelburg and Norbert Kersken (Leipzig, 1996).Back to (2)

3. Henryk Lulewicz, Gniewów o uni? ci?g dalszy: stosunki polsko-litewskie w latach 1569-1588 (Warsaw, 2002). Back to (3)

The author is happy to accept this review and constructive comments by Professor Karin Friedrich but does not wish to comment further.

Source URL:https://reviews.history.ac.uk/review/2131

\section{Links}

[1] https://reviews.history.ac.uk/item/175177 